\title{
Public servants coping with competing demands on their agency in client relationships
}

Public servants

coping with competing

demands

\author{
Tiina Tuominen \\ Faculty of Management and Business, Tampere University, Tampere, Finland, and \\ Mervi Hasu \\ Faculty of Educational Sciences, University of Oslo, Oslo, Norway
}

\section{5}

Received 2 May 2019 Revised 19 September 2019 17 February 2020 6 May 2020

Accepted 7 May 2020

\begin{abstract}
Purpose - This paper analyzes how public servants who work with young people discursively cope with competing demands on their agency, defined as their orientation toward and capabilities to influence their clients. Previous studies revealed how public servants treat their clients when facing competing demands but paid less attention to how public servants define their agency.

Design/methodology/approach - Micro-level discourse analysis is applied to analyze how public servants represent their agency in client relationships, drawing on interviews with nine individuals in a Finnish city who work with young people lacking jobs or school placements.

Findings - Instead of describing their agency coherently, the interviewees applied several discourses to represent their agency differently in relation to different demands. This ability to navigate contradictory discourses is discussed as reflexive discursive coping strategy, which enables public servants to maintain a positive image of their agency despite tensions at work.

Research limitations/implications - Although the method does not allow direct generalizations, it reveals discursive strategies likely to be found in many contemporary public organizations.

Practical implications - The study indicates a need to better acknowledge and nurture the multifaceted nature of agency to improve service quality.

Originality/value - The findings deepen the view on tensions in public servants' work and show that diverse discourses not only create anxiety but also help individuals dealing with contradictory work.
\end{abstract}

Keywords Agency, Client relationships, Discourse, Coping strategy, Public servant, Young people

Paper type Research paper

\section{Introduction}

Public servants face many competing demands on their agency in contemporary client relationships (Koppell, 2005; Schott et al., 2016). When serving youth, public servants should simultaneously support the client and exercise authoritative control (Siurala, 2014), for example. These demands derive partially from the work itself, but they are emphasized in an increasingly "hybrid" discursive context with alternative perspectives on client relationships (Bryer, 2007; Denhardt and Denhardt, 2015; Hirvonen, 2014; RostilaandVinnurva, 2013). Previous studies showed how public servants view and categorize their clients in such situations (Bäcklund et al., 2014; Bryer, 2009; Rosenthal and Peccei, 2006, 2007) and acknowledged that defining one's agency is likely to be difficult (Hirvonen, 2014; Schott et al.,

(C) Tiina Tuominen and Mervi Hasu. Published by Emerald Publishing Limited. This article is published under the Creative Commons Attribution (CC BY 4.0) licence. Anyone may reproduce, distribute, translate and create derivative works of this article (for both commercial and non-commercial purposes), subject to full attribution to the original publication and authors. The full terms of this licence may be seen at http://creativecommons.org/licences/by/4.0/legalcode.

The authors are grateful to Mikko Lehtonen and Eveliina Saari for their contribution in data collection and to Reijo Miettinen and Laura Seppänen for their comments.

Funding: The research was funded by Tekes, Evald and Hilda Nissi Foundation and the Finnish Work Environment Fund (grant no. 115288).

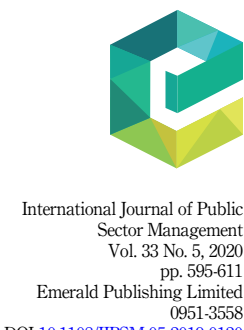

DOI 10.1108/IJPSM-05-2019-0120 
IJPSM

33,5

596
2016). However, there is little empirical evidence of how public servants cope with these challenges.

This study analyzes public servants' discursive practices to reveal how they represent their agency in client relationships, as well as the tensions public servants face and the solutions they construct when building and using these representations. The study builds on interviews with public servants in a cross-organizational service system that helps young people transition to secondary school or work life and avoid unemployment, mental health problems and crime. In welfare states such as Finland, these types of public servants who ensure citizens' survival in a complex information society are increasingly important (Castells andHimanen, 2002; Miettinen, 2013). Simultaneously, public servants face challenges in prioritizing different demands (Siurala, 2014). The discourse analytic method details how they navigate different demands when describing their agency in relation to their clients (Dobson, 2015; Potter and Wetherell, 1987).

The study provides new knowledge about public servants' work situation, the role of multiple discourses in their work, and their discursive coping strategies. The findings suggest that public servants can and need to use discourses strategically to adapt to challenges in welfare states and to express the multifaceted nature of their agency in a legitimate way. Therefore, it is argued that the hybrid discursive context can provide resources for coping with the inherent tensions in client relationships, instead of only creating stress and anxiety (cf. Teelken, 2015). However, to reach an organizational solution, multidimensionality of agency should be considered when defining administrative role expectations (e.g. Stout, 2009).

The paper begins by defining the concept of agency in client relationships. Then a review of how public administration discourses characterize client relationships and how public servants react to the hybridity of demands and discourses follows. The empirical research design and findings regarding how the interviewees described their agency in client relationships are discussed. A discussion of the key implications and limitations of the study concludes the paper.

\section{Theoretical background}

\section{Public servants' agency in relation to youth clients}

Analyses of how public servants characterize their agency in client relationships comprise a topical theme, as researchers from different fields stress the role of service encounters and relations between public servants and clients in value creation (Bartels, 2013; Bartels and Turnbull, 2019; Stout and Love, 2017; FitzPatrick et al., 2015; Osborne et al., 2016). This paper applies a conceptualization of agency emanating from sociology, where it explains purposeful social action. Agency is generally discussed in terms of either actors' orientation toward the situations they face (Emirbayer and Mische, 1998) or their power to influence their own or other actors' situations (Burkitt, 2016; Giddens, 1984). Both conceptualizations assume reciprocal relations between (1) agency and structure and (2) actors with different positions and interests. In line with these general assumptions, public servants' agency in client relations is understood in this paper as their orientation toward and ability to influence their clients. Agency draws on and becomes realized through their relations with many actors, their (professional) background and discourses and resources at work (Dobson, 2015; Donati and Archer, 2015). While acknowledging these multiple sources and constraints, and the organizational, political and frontline arenas, where public servants exercise their agency, the paper focuses on agency in relation to the client.

Studies of youth services often view public servants as agents who help young people develop their own agency (Juvonen, 2014; Siurala et al., 2014). Young people's agency - their ability to develop and pursue different aims (Archer, 2003) - is just forming, and social 
relations may influence this ability heavily (Donati and Archer, 2015; Juvonen, 2013, 2014; Raffo and Reeves, 2000). However, it is not necessarily easy for public servants to define their agency in client relations. Previous studies revealed paradoxical (that is, unsolvable) tensions in their work, partially because the clients, organizations, occupations and political systems promote competing goals (Koppell, 2005), creating discrepancies between goals and resources and between demands for obeying formal scripts and creating individualized service (Lipsky, 1980; Tummers et al., 2015). Public servants also have to deal with qualitatively different goals. Previous studies suggested that youth workers often face tension between controlling clients' harmful intentions (to create public value via socializing young people) and encouraging them to exercise autonomous agency (to create private value via supporting clients' self-efficacy; Siurala, 2014). Furthermore, youth workers should help young people without making them dependent on such help (Juvonen, 2013). These tensions might problematize how public servants characterize their agency in client relationships: how they represent themselves and their clients, define their goals and define limitations and methods in client interactions. Although these tensions can be inbuilt in client relationships, they might be accentuated in the increasingly variable discursive context.

\section{Client relationships in public sector discourses}

Discourses are ways of representing the world (Fairclough, 2003). Public administration discourses provide different views on themes related to agency, such as motivation, administrative discretion and legitimacy. Margaret Stout (2013), in her study of legitimacy in decision-making, identified three ideal types among public administration traditions. Each assumes different roles for public servants, which is shown in public administration discourses reflecting these ideals.

The first ideal type, the constitutional tradition, views public servants as bureaucrats accountable to a political system ensuring democratic legitimacy (Stout, 2013). Traditional public administration discourses reflect this idea by de-emphasizing public servants' individuality and assuming that their administrative discretion - the exercise of individual judgment at work-must be constrained by rules and procedures to avoid corruption and personal projects (Bartels, 2013). Simultaneously, as bureaucrats, public servants decide on behalf of citizens, who are viewed as self-interested or irrational (Stout, 2013). Thus, client relationships are unidirectional and authoritative: Citizens rely on administrators' goodwill and ability to create public value (Bryson et al., 2014; RostilaandVinnurva, 2013; Vigoda, 2002). In the youth context, traditional educational psychology and vocational psychology reflect similar notions, shown in practices where, for example, researchers and authorities enhance adolescents' career-choice preparedness and transitions with little or no goalformulating initiative by the adolescents (Koivisto et al., 2011; Lazarides et al., 2017).

The second ideal type, the discretionary tradition, views public servants as entrepreneurs responsible for good outcomes (Stout, 2013). Due to their professional and managerial expertise and ethics, they have discretion when pursuing various performance criteria. New public management (NPM) discourse exemplifies these ideas, presenting client relationships as relationships between entrepreneurial service providers and sovereign customers (Alford, 2002). However, whereas NPM emphasizes both parties' agency, in the youth context NPM has also increased performance measurement and client monitoring (Siurala, 2014). This has led youth workers to emphasize the professional nature of client relationships and to represent themselves as advocates for youth (Siurala et al., 2014).

The third ideal type, the collaborative tradition, describes public servants as stewards responsive to the citizenry (Stout, 2013). This tradition embraces direct democracy, where public servants facilitate citizen communities in achieving their purposes. Discourses about new public service (Denhardt and Denhardt, 2015), participatory democracy (Boyte, 2011) and collaborative governance (Emerson et al., 2011) referred to as "collaborative discourses," 
IJPSM 33,5

\section{8}

illustrate these ideas to some extent. They view citizens as capable of developing the common good beyond their own needs (Bryson et al., 2014; Stout and Love, 2015; Vigoda, 2002). In services provided for the young, sociocultural and critical psychology traditions promote similar ideas, shown in practices where adolescents' viewpoints are embraced when jointly analyzing their life and formulating interventions (Nordlund et al., 2019), as an example.

These discourses differ in several themes related to agency in client relationships. First, they disagree about whether administrative discretion should be controlled or whether it enables responsible behaviors of moral public servants (Bartels, 2013; Evans, 2010; Lipsky, 1980). Second, and more directly related to client relationships, the discourses vary regarding whether public servants should primarily serve the political system, individual clients or society as a whole-which likely influences their orientations toward their direct clients. Third, the discourses treat power relations differently: The constitutional tradition emphasizes bureaucracy's power over clients, whereas the other traditions treat public servants and clients more or less as equals. However, the discretionary tradition assumes that these actors pursue different goals, while many of the collaborative discourses treat agency as embedded in relations where mutually satisfactory outcomes are possible (Bartels and Turnbull, 2019; Burkitt, 2016; Dobson, 2015; Stout and Love, 2015).

\section{Public servants' reactions to competing discourses}

Previous studies showed that discourses influence public servants' interpretations and identities and provoke different reactions (Bévort and Suddaby, 2016; Skelcher and Smith, 2015; Teelken, 2015). These reactions are evident when coexisting discourses provide contradictory ideas about work (Bäcklund et al., 2014; Bryer, 2009; Olakivi and Niska, 2017). Organizations may respond to such hybridity in discourses by emphasizing and blending them in different ways (Fairclough, 2005). Nevertheless, new discourses often pose challenges for individual public servants. For example, some studies showed that NPM may suffocate genuinely cooperative client relationships if the clients do not exhibit typical customer characteristics (Alford, 2002; Rosenthal andPeccei, 2006). However, employees are capable of dealing reflexively with different discourses, to some extent (Aschhoff and Vogel, 2018; Teelken, 2015). Rosenthal and Peccei showed how tensions between client narratives in an employment agency led employees to blend these narratives (2007) and to categorize individual clients, emphasizing one narrative or the other (2006).

Although these studies discussed how public servants react to alternative discourses, the focus was on describing and categorizing clients (Bäcklund et al., 2014; Bryer, 2009; Lipsky, 1980; Rosenthal and Peccei, 2006, 2007) or values (Aschhoff and Vogel, 2018). By addressing agency, the present study adds to these studies by revealing how public servants justify their own capabilities and orientations in these situations.

\section{Research methods and data}

The study focuses on public servants who help young people lacking jobs or school placements. Interviews with these actors were analyzed using a method based on Potter and Wetherell's (1987) study of interpretive repertoires, which they defined as "recurrently used systems of terms used for characterizing and evaluating actions, events and other phenomena" (p. 149). This method helps make visible the tensions the interviewees face in defining their agency, and their discursive ways of coping with these tensions. However, this paper applies the concept of representation of agency instead of interpretive repertoire, as the former concept is more common and accessible for readers across disciplines. Both concepts refer to linguistic resources that draw from broader discourses (Fairclough, 2003; Potter, 2012), different from beliefs and other mental entities (Potter and Wetherell, 1987). Although 
discourses, beliefs and non-discursive practices might influence one another (Archer, 2003; Fairclough, 2003), the focus is entirely on language. It is assumed that the interviewees might use language strategically, even if it contradicts their personal beliefs (Potter andWetherell, 1987).

This study assumes that representations of agency can borrow ideas from several discourses and be identified across different discourses (Fairclough, 2003). Therefore, attention is also paid to links between the representations of agency and public administration discourses, and what these connections might reveal about coping with contemporary work situations.

\section{The empirical context: service system that prevents youth exclusion from education and work}

The interviewees work in a cross-departmental service system in a city employing 11,000 public servants. The system was created to facilitate young people's transitions from basic education to secondary education or work life, as these transitions were considered challenging for many. In general, the rising education levels have increased these challenges in Finland (Nurmi et al., 2002), while youth are expected to be independent and responsible (Juvonen, 2014). After compulsory basic education, 15- and 16-year-olds must choose between a vocational pathway at secondary-level vocational schools and an academic pathway at upper secondary schools. Despite a comprehensive public schooling system, at the time of the study more than $10 \%$ of young people failed to make this choice or dropped out of school, facing the risk of exclusion from education and work (Koivisto, 2010; Statistics Finland, 2009).

Due to increased debt since the 2000s, the city has rationalized its actions while giving departments some discretion in their strategies. After realizing the costs of youth exclusion, three departments-Education, Health and Social Services and Leisure and Citizen Services - assumed shared responsibility for at-risk youth. They promised to "never leave a friend behind" and guaranteed secondary education for everyone. They developed the studied service system by integrating new and existing services, increasing school placements and improving cross-departmental communication. They increased guidance throughout the educational pathway and traced everyone without a school placement or job. For example, of the 2,433 pupils graduating during spring 2010, they contacted all 458 who lacked a secondary school placement. Cross-organizational teams counseled and placed the youth in schools or workshop activities, or provided social and healthcare services.

Generally, the service system demonstrates how different departments tackle a mutual problem, which is not easy (Bartels, 2018). This system also provides a fruitful arena for analyzing competing demands on public servants' agency: A mix of ideas coexists when public servants address the problem together.

\section{Data collection strategy and empirical data}

To analyze language use in detail (Potter, 2012), nine public servants from different tasks and organizational levels were purposively selected for interviews. The interviewees represent basic education and youth and adult education from the Education Department, and youth services from the Leisure and Citizen Services Department. Collaboration between these areas forms the core of the service system. The interviewees included managers and developers who designed and coordinated service processes and frontline employees who traced and advised young people and organized workshop activities. Semi-structured interviews were conducted with each lasting $1-2 \mathrm{~h}$ and covering questions about the services, clients and client relationships, service development, and the interviewees' work and wellbeing (see Appendix 1 for an interview guide). The interviews were recorded and fully transcribed. 
IJPSM

33,5

600

\section{Data analysis}

The analysis aimed to inductively identify interviewees' representations of their agency, but theoretical conceptualizations were used to identify manifestations of agency in the data. The analysis comprised four iterative tasks, guided by Potter and Wetherell's (1987) suggestions and conducted using Atlas.ti software.

The first task involved open coding of the interviews to identify excerpts where interviewees specifically discuss client relationships, resulting in 150 excerpts. The second task involved distinguishing and categorizing the representations of public servants' agency in these excerpts. Due to reciprocity in client relationships, attention was paid to the agency of the public servants and their clients. As agency refers to the human potential to act purposefully and have an effect (indicating that agency is realized via social interactions; Archer, 2003), the focus was on the verbs and adjectives used to address public servants, clients and their interactions. Attention was paid to whether the actors were presented as active or passive and whether their interactions were personal or general (Fairclough, 2003, pp. 145-146). The initial analysis indicated that there were several contrasting representations: Clients were described either as people for whom things happen or as active agents but with varying intentions. Consequently, public servants were described as actors who decide on behalf of clients, negotiate with them, or learn from them, with each account manifesting a particular understanding of their agency.

A comparative tactic (Miles and Huberman, 1994) was used to assess similarities and contradictions that could help distinguish between different representations. This analysis revealed three possible representations of public servants' agency, each accompanied by a compatible characterization of the client and client relationship. All nine interviewees applied these three representations, although with different emphases. The representations were labeled (1) responsible public servant engaged in an authoritative relationship with incapable young people, (2) empathetic public servant engaged in a personal relationship with volatile young people and (3) responsive public servant engaged in a collaborative relationship with powerful young people. The representations were specified by analyzing themes that distinguished them from one another. This comparison iterated with the third task discussed below, as some themes were informed by literature while others emerged from the data. The identified themes included (1) adjectives characterizing public servants and clients, (2) the clients' problems, (3) orientation toward the client, (4) power relations, (5) public servants' agentic actions and (6) sources of public servants' agency.

The third task involved estimating whether the representations reflected broader public administration discourses. The terminology and ideas in the three representations were compared to previous research on public administration (Alford, 2002; Bryson et al., 2014; Denhardt and Denhardt, 2015; Siurala et al., 2014; Stout, 2013), particularly on research in the Finnish context (Bäcklund et al., 2014; Häikiö, 2012; Juvonen, 2014; Kallio et al., 2015). This analysis indicated that the interviewees drew on several available discourses but combined their ideas in ways that were relevant to their work.

The fourth task addressed the functions of the representations: Why did the interviewees construct three representations instead of consistently using one? This in-depth analysis focused on 43 rich excerpts manifesting the terminology of each representation and 24 excerpts in which the interviewee shifted between representations (e.g. Q7 and Q10 in Findings). The latter were chosen because contradictions between representations can reveal their different functions (Potter and Wetherell, 1987). Therefore, attention was paid to inconsistencies and changes in speech to identify the role of each representation in its textual context. This analysis revealed how the representations worked together when the interviewees aimed to provide a holistic account of their agency in client relationships.

Taken together, the analysis shows how and why the interviewees constructed and used the identified representations, and what these representations reveal about the interviewees' 
reactions to competing demands and contradictory discourses in their work. In the next Public servants section, these findings are presented.

\section{Findings}

The findings vividly demonstrate the contradictions in the interviewees' language: All demands interviewees discussed their agency in client relationships using three mutually contradictory representations. Each representation is presented using illustrative quotations. Their connections with administrative traditions and discourses are also assessed. Finally, the functions of the representations are analyzed to suggest why the interviewees used three instead of one.

\section{Representation 1: Responsible public servant engaged in an authoritative relationship with incapable young people}

The first representation (R1) characterizes public servants as responsible and competent representatives of the service system, aiming to improve clients' capabilities. Their agency is strong in relation to the client, who is passive and needs direction. Clients are characterized as having no direction in their lives and as insufficiently capable of surviving in society, indicating a lack of agency. Instead, they have "problems" or "inadequate skills," and they "stay at home" and "cannot manage" school, some due to being "sick." However, clients are not blamed; instead, their problems derive from the competitive educational system. As representatives of this system, the interviewees represent themselves as having a collective responsibility to solve clients' problems. This notion reflects accountability to the city and responsibility to help youth.

R1 represents the service system as a solution to the problem, and it was typically applied when discussing the system's formal aims. Quotation 1 (Q1) demonstrates how the system was characterized as a comprehensive pipeline, comprising several steps for developing clients' capabilities.

Q1. We complement the promise that the city has made that there will be a place for everyone graduating from comprehensive school, secondary education, on-the-job training, in a workshop or some other positive thing. Or if someone needs treatment, he/she goes there and then enters this pipeline (Manager 4, Youth services).

The public servants' task in $\mathrm{R} 1$ is to diagnose clients' needs using research-based, formalized methods and metrics and place clients correctly in the service system. The client relationships in $\mathrm{R} 1$ are distant and authoritative, and public servants are characterized as having power over clients. As an example, Q2 shows how a frontline worker used R1 to characterize meetings in which public servants, clients and their parents resolve the clients' problems. The client does not have a say. The parents are active but cannot diagnose the problem. Despite parents' hesitation, public servants are better equipped to distinguish the clients' needs from their will and to direct them to proper services.

Q2. Sometimes, in the middle of the meeting, you realize that this young person needs something else, but the parents are like, "He needs to go to school," and they can't see that the boy wouldn't survive. It is sometimes terribly difficult to explain it. . . Luckily, a doctor is sometimes involved, and states directly that this young person will spend the winter just getting him/herself together (Frontline worker 1, Youth services).

Although public servants' agency is strong in relation to the client in R1, their individual-level discretion is low: Their agency emanates from the tools and processes in the service system. Several connections can be identified between R1 and the public administration discourses and traditions. The assumptions about knowledge asymmetry and the decision-making 
IJPSM 33,5

602

power of public authorities are in line with traditional public administration discourse (Bryson et al., 2014; Vigoda, 2002) and with traditional educational and vocational psychology (Koivisto et al., 2011), which the interviewees are likely to know well. The assumption about weak individual-level discretion also corresponds to traditional public administration discourses (Stout, 2013). However, instead of stressing the political system, R1 assumes an orientation toward society and the collective aim to "leave no one behind." Furthermore, even if individual-level discretion is low, R1 touches on the entrepreneurial ability of the investigated departments that created the service system. These ideas and the emphasis on methods and metrics might be associated with discretionary traditions and NPM (Siurala, 2014; Stout, 2013). Therefore, R1 seems to combine ideas from traditional and entrepreneurial discourses in its own way.

\section{Representation 2: Empathetic public servant engaged in personal relationships with volatile young people}

Occasionally, the interviewees worried about finding clients, legislative restrictions and clients' future after transferring responsibility along the pipeline. This led the interviewees to use another representation (R2), which describes public servants as empathetic and supportive. Unlike R1, R2 suggests that young people have agency in the form of many intentions, albeit they are volatile or not beneficial. The clients are "unrealistic," "volatile," "roguish," "dropping out of school," and sometimes, do not want to be served. The problem is that strict and contradictory rules and attitudes lead clients to lose trust in authorities, "abandon" society, and "play their own game." Therefore, R2 characterizes public servants as empathetic supporters who personally reconnect with clients. For example, close relationships at vocational schools are advocated to overcome the students' negative images of themselves and the educational system.

Q3. We wanted there to be a single adult because many young people have learning problems. They might have been skipping classes in basic education; they might have extremely negative conceptions of themselves as learners. They haven't received positive feedback or experienced success in previous schooling. They need a support person, someone at their side all the time (Manager 3, Vocational college).

R2 suggests that a personal relationship helps public servants understand clients' situations and negotiate a solution. Q4 demonstrates how the agency of public servants differs from R1.

Q4. I have customers who went to school, who maybe come by for a coffee once in a while, and it's nice to see that, "Hey, you're doing fine, and you got that placement, we just helped a little"; for instance, if they get a special vocational study placement. And sometimes, you see it quickly. For instance, yesterday, two girls, who are doing nothing now, they will probably start in an [activity] group. However, it's possible that the situation will change next week that they'll quit. I mean, there are fleeting feelings of success, but in adolescents' lives - as in anyone's life - changes are rapid and quite impulsive (Frontline worker 2, Youth services).

In Q4, the interviewee suggested that public servants "help a little," while clients are active (lines $2-3)$; this involves reciprocity and negotiation, instead of diagnosing and directing. The clients' choices are respected. Furthermore, Q4 addresses clients' volatile motivations instead of inadequate skills: Clients interpret situations and change directions unpredictably (lines 5-8), weakening the effects of the linear "pipeline model" of the service system. The interviewee has personal opinions and feelings, such as judgment and frustration, because she cannot be sure that her work will pay off (lines 6-7). Nevertheless, she remains empathetic; rapid changes can happen to anyone (lines 7-8). In R2, public servants' agency draws on interpersonal skills and 
work experience rather than on the service system and research-based information. Public servants Nevertheless, their agency is constrained by and relative to the clients' will and actions.

Comparisons reveal similarities between R2 and collaborative discourses that emphasize individual and cooperative approaches toward each client (Bryson et al, 2014; Rosenthal and Peccei, 2007). R2 assumes that public servants' experiences and skills give them some discretion in relation to the service system but not much power over the client: The agencies of the public servant and the client are interdependent. However, $\mathrm{R} 2$ includes traditional ideas indicating that clients are irrational and need guidance (Bartels, 2013). Nevertheless, public servants are not authoritarian as such relationships are seen to deepen clients' problems. The role of a responsive facilitator that Stout (2013) associated with the collaborative tradition describes R2 well.

\section{Representation 3: Responsive public servant engaged in a collaborative relationship with powerful young people}

The third representation (R3) emphasizes clients' agency and characterizes public servants as responsive learners who must meet clients' expectations. Although R3 emphasizes responsiveness, public servants are not emotionally involved as in R2 but take a more distant stance. Their agency draws on neither the service system nor a trusting relationship but on their ability to collectively develop the service based on client feedback. Young people are described as "regular customers" who "have their needs" and "are active themselves," possessing relevant knowledge for service development. They are listened to and served well. Terms like "co-creation," "inclusion," and "co-design" are used. Q5 and Q6 illustrate language typical of R3 ( $I=$ interviewer, $R=$ respondent).

Q5. I: The users of your services, what do they think about them? R: Well, we ask this, and they like them; feedback is typically good. But it is our basic principle, we have this inclusive model. They participate in workshops, and they are listened to, and the activities are developed together with them (Manager 4, Youth services).

Q6. It derives from the competitive situation: experiences spread among youngsters, the good things and the bad things. Customer-drivenness takes place that way, and these [service providers], they have to develop their activities continuously (Manager 2, Youth and adult education).

As these quotations illustrate, R3 includes business terms, such as "competitive situation" and "customer-drivenness." Clients and public servants are equal in terms of agency, which enables co-creation. This representation speaks little about public servants' individual-level discretion. Rather, it suggests that discretion takes place collectively when developing the service system.

It seems that R3 applies many ideas associated with collaborative public administration discourses, but it assumes an orientation toward clients as a collective instead of as individuals. The business terminology and the characterization of young people as customers and collaborators suggest that R3 combines ideas from collaborative approaches and NPM (Bäcklund et al., 2014; Denhardt and Denhardt, 2015; Stout, 2013) to produce the notions of respected young persons and responsive public servants. Note that R1 and R2 focus on solving clients' problems, but R3 focuses on another dimension of client relationships: service (co)development. When using R3, the interviewees soon defined limitations for it, justifying why the term "customer" does not apply to their incapable and volatile clients, returning to R1 and R2.

The functions of the three representations: coping with tensions

The findings above indicate that the interviewees represented themselves as different types of agents when characterizing different aspects of their client relationships. Furthermore, the 
IJPSM 33,5

604

representations seem to adopt ideas from several discourses to serve the interviewees' purposes. A pressing question is why such complex and mutually contradictory representations were constructed and applied by all nine interviewees. Moreover, the interviewees used the representations when describing relations with the same young people, which exclude the possibility that the representations were simply used to categorize clients with different needs (cf. Rosenthal and Peccei, 2006). The interview excerpts in which the interviewee iterated between representations revealed a likely response, indicating that each representation helped explain certain aspects of agency, but when the interviewees reflected on their client relationships in light of different aims, the use of a single representation raised new challenges. The analysis suggests that the interviewees tackled tensions between three central aims in the service system: between their own responsibility (as care) and the intention to support clients' self-sufficiency and between responsibility (as coercive) and responsiveness to clients' will (see also Dobson, 2015). It is possible that the three representations helped the interviewees address these tensions when characterizing their agency, as discussed next.

The tension between the responsibility to help the client and the intention to support the client's self-sufficiency, noted by previous researchers (Juvonen, 2014; Siurala, 2014), was often addressed by interviewees. Q7 illustrates how an interviewee used R1 and R2 to manage this tension. The interviewee starts with R1, emphasizing public servants' responsibility (lines 1-5), but notes that solving problems on clients' behalf does not help them in the long term, recognizing limits in the official view. Thus, he moves to R2 (lines 5-9), which gives agency to and enables the client to take responsibility. By using the two representations, the interviewee seeks a balance between responsible action and clients' self-sufficiency.

Q7. [R1] In our modern society, no one survives. There're no jobs for scavengers. Simple jobs don't exist. Everyone must get a decent study placement to get a hold of their life. You need IT and other skills. And this leads to a situation where [in this service system], no one is left behind, and everyone is taken care of, and if something doesn't work, we'll hear about it. We need to hear. We need to find solutions. [R2] The flip side is, now I'm speaking a little off-topic, that we should not pamper them too much. We need to guide them toward independence and self-sufficiency. This worries me a bit: the practices need to encourage the young person to make decisions herself; she is supported, but she takes responsibility (Manager 1, Basic education).

Furthermore, R1 casts public servants as the only actors capable of comprehending young people's actual needs, which warrants their responsibility but ignores the clients' will (see also Koppell, 2005). Another interviewee treated these tensions between responsibility (as coercive) and responsiveness to clients' demands in Q8, where she worries about clients who "manage to slip" through their service "nets." She presumably refers to passive clients involuntarily falling out, but the terms could also refer to clients intentionally avoiding the system. Her problem is that R1 ignores the possibility that clients can rebel against the service system. To solve the problem, the interviewee uses R2 when returning to the topic in Q9.

Q8. I: What are the most challenging things in this service system?

$\mathrm{R}$ : [R1] Probably how we might reach everyone. Even though our mental model is that no one will fall through, still there are. . . even though we have these safety nets, and the idea is that if one falls through one net, there will be another to catch them. But somehow, there are those who manage to slip through every net. (Frontline worker 2, Youth services)

Q9. [R2] On the other hand, there will always be those who. . because our services are voluntary, and these models by no means suggest that the municipality would control and follow everyone, even though it might seem so-we follow the numbers, 
not the individuals. They are, the services are voluntary, and they are offered, and no one is forced to receive them. And there are, of course, always those who do not want to receive them. (Frontline worker 2, Youth services)

This suggests that $\mathrm{R} 2$ explains failures in reaching everyone without downplaying public servants' agency; some clients cannot be helped because of their own will. Rather than blaming themselves, the interviewees' responsiveness and professional ethics become highlighted; they are concerned but respect clients' will.

R3 helps downplay the connotation of responsibility as coercive further by suggesting Public servants coping with competing demands that public servants respond to clients' voices at a strategic level. However, this representation sits uneasily with the other representations, in which clients' agency is limited. In Q10, an interviewee iterates between all three representations to describe public servants as simultaneously responsive, empathetic, and responsible. She starts with R3 (lines 2 and 7-8) when discussing customer feedback. Then she sets limits for its usefulness and applies R1 to refer to the knowledge asymmetry (lines 2-7). Then she reconfirms the importance of customer feedback (R3, lines 7-8) but also research-based evidence (R1, lines 8-9). Finally, she moves on to R2 to show that although clients are unrealistic, their decisions are respected (lines 9-13).

\begin{tabular}{|c|c|c|c|c|}
\hline $\begin{array}{l}\text { Public servant as } \\
\text { agent }\end{array}$ & $\begin{array}{l}\text { Representation } 1 \\
\text { Responsible and } \\
\text { authoritative }\end{array}$ & $\begin{array}{l}\text { Representation } 2 \\
\text { Empathetic listener and } \\
\text { supporter }\end{array}$ & $\begin{array}{l}\text { Representation } 3 \\
\text { Responsive service } \\
\text { provider }\end{array}$ & \\
\hline Clients as agents & $\begin{array}{l}\text { Incapable, passive or sick, } \\
\text { cannot comprehend their } \\
\text { own needs }\end{array}$ & $\begin{array}{l}\text { Volatile, unrealistic, } \\
\text { impressionable, "play their } \\
\text { own game" }\end{array}$ & $\begin{array}{l}\text { Powerful, active, chooses } \\
\text { and collaborates }\end{array}$ & \\
\hline $\begin{array}{l}\text { Origins of clients' } \\
\text { problems }\end{array}$ & $\begin{array}{l}\text { Knowledge requirements } \\
\text { and competitive } \\
\text { educational system }\end{array}$ & $\begin{array}{l}\text { Fragmentation of society, } \\
\text { lack of trust between } \\
\text { society and youth }\end{array}$ & N/A & \\
\hline $\begin{array}{l}\text { Orientation toward } \\
\text { clients }\end{array}$ & Distant, authoritative & Personal, empathetic & Distant, professional & \\
\hline Power relations & $\begin{array}{l}\text { Public servant's agency is } \\
\text { high in relation to the } \\
\text { client's agency }\end{array}$ & $\begin{array}{l}\text { Public servant's agency is } \\
\text { relative to the client's } \\
\text { agency }\end{array}$ & $\begin{array}{l}\text { The public servant and } \\
\text { the client are equally high } \\
\text { in agency }\end{array}$ & \\
\hline $\begin{array}{l}\text { Public servants' } \\
\text { agentic actions }\end{array}$ & $\begin{array}{l}\text { Diagnoses clients' needs } \\
\text { and places them correctly } \\
\text { in the "pipeline" }\end{array}$ & $\begin{array}{l}\text { Builds personal, trusting } \\
\text { relationship and finds a } \\
\text { solution with the client }\end{array}$ & $\begin{array}{l}\text { The client is served well, } \\
\text { and the service is co- } \\
\text { developed }\end{array}$ & \\
\hline $\begin{array}{l}\text { Sources of public } \\
\text { servants' agency } \\
\text { (resources and } \\
\text { constraints) }\end{array}$ & $\begin{array}{l}\text { The service system and } \\
\text { research-based } \\
\text { knowledge. Individual } \\
\text { discretion is low. } \\
\text { Outcomes depend on } \\
\text { other actors and } \\
\text { structures }\end{array}$ & $\begin{array}{l}\text { Professional experience } \\
\text { and interpersonal skills. } \\
\text { Individual discretion is } \\
\text { high, but outcomes depend } \\
\text { on clients' agency } \\
\text { (particularly on will) }\end{array}$ & $\begin{array}{l}\text { Service development } \\
\text { practices. Discretion takes } \\
\text { place at the collective level } \\
\text { within co-creative } \\
\text { relationships }\end{array}$ & \\
\hline $\begin{array}{l}\text { Public } \\
\text { administration } \\
\text { discourses } \\
\text { highlighting similar } \\
\text { ideas }\end{array}$ & $\begin{array}{l}\text { Traditional public } \\
\text { administration and } \\
\text { vocational psychology. } \\
\text { Some ideas associated } \\
\text { with NPM }\end{array}$ & $\begin{array}{l}\text { Collaborative discourses. } \\
\text { Some ideas associated } \\
\text { with traditional discourses }\end{array}$ & $\begin{array}{l}\text { Collaborative discourses } \\
\text { and NPM }\end{array}$ & \\
\hline $\begin{array}{l}\text { Key function of the } \\
\text { representation }\end{array}$ & $\begin{array}{l}\text { Describes the service } \\
\text { organization as well- } \\
\text { functioning and } \\
\text { responsible: Clients } \\
\text { capabilities can be } \\
\text { measured and improved }\end{array}$ & $\begin{array}{l}\text { Emphasizes public } \\
\text { servants' ethics while } \\
\text { explaining failures: } \\
\text { Failures happen because } \\
\text { the client's will must be } \\
\text { respected }\end{array}$ & $\begin{array}{l}\text { Describes the service } \\
\text { organization as } \\
\text { responsive and inclusive: } \\
\text { Customers can help to } \\
\text { improve the service }\end{array}$ & $\begin{array}{r}\text { Table } 1 . \\
\text { Overview of the } \\
\text { representations and } \\
\text { their functions }\end{array}$ \\
\hline
\end{tabular}


IJPSM

33,5

\section{6}

Q10. I: How do customer needs and feedback guide service development?

R: [R3] Yes, I think we all agree about how it should be. [R1] But it [customers' feedback] cannot be the only guiding force because they also have, there's this knowledge asymmetry; they also have less knowledge about it. And youth services, education in general, is a field where the customer isn't always right. And the customer is not a customer in the typical sense, and in youth services, we don't generally like to speak about customers. [R3] But surely more should be done. We are on a good track; we genuinely want that. [R1] And the starting point is that we are also aware of the youngsters' needs through our networks and partners. [R2] And sometimes they are, how should I put this? For instance, counseling is not always easy because their ideas may be unrealistic, and they have their favorite occupations, but we cannot. . . They need to be genuinely able to decide themselves. We cannot limit them much. (Manager 4, Youth services)

Q10 demonstrates contradictions in public servants' work and how the three representations help describe the public servants as simultaneously responsible, empathetic and willing to react to feedback - thus, emphasizing different aspects of their agency. Table I summarizes the empirical findings, showing the key differences and functions of the representations.

\section{Discussion}

This study aimed to provide micro-level knowledge of competing demands on public servants' agency in client relationships and how the interviewees linguistically cope with these demands. The analysis revealed that the interviewees combined terms and ideas usually connected to contradictory, coexisting public administration discourses to construct different versions of their agency and justify their actions as responses to different goals in their client relationships. That the interviewees had to use different representations demonstrates inherent tensions in their work. Furthermore, although the use of multiple representations might produce ambiguous accounts of their work, it seemed to comprise an ability that is interpreted as the interviewees' reflexive discursive coping strategy. It comprises their ability to navigate competing discourses and use them to construct a positive image of their agency, despite tensions in their work. This discursive ability helped the public servants describe themselves and their organization simultaneously as responsible, empathetic, and responsive agents who serve society and young people.

The study provides two key insights. First, it shows the limitations of a single public administration discourse in describing public servants' agency in a complex welfare state (Stout, 2009). In the study context, traditional public administration discourses highlighted the accountability and authority of public servants and the service system as a source for agency but undermined the voluntary nature of the service and the need to encourage clients' self-sufficiency. Collaborative discourses highlighted equality and respect for clients' will, while the NPM discourse emphasized clients' autonomous agency and public servants' responsiveness and expertise, but neither discourse addressed the challenges of knowledge asymmetry. The empirical representations identified in the study followed neither the ideal type traditions discussed by Stout (2013) nor public administration discourses in their pure forms. Although such ideal types and macro-discourses transcend empirical, local approaches (Stout, 2013), the representations of agency identified in the study include a complex mixture of these resources, mediated by local contextual circumstances. This indicates that although political or even organizational-level talk might be ideological, it is likely that public servants facing actual work practices must use several discourses in diverse combinations to grasp the complex expectations of their agency.

Second, whereas previous studies often treated hybridity as a challenge for public servants and suggested that they choose among existing logics (Pacheand Santos, 2013; Teelken, 2015), 
this study identified micro-discursive ways to benefit from multiple contradictory discourses. Whereas talk does not solve the tensions at work, the availability of multiple discourses may facilitate coping. The way interviewees shifted between the representations illustrates their knowledge and ability to construct a balance between the different demands while simultaneously revealing how these demands cause tensions in client relationships. This reflexive discursive coping strategy may be necessary for public servants to maintain a positive and constructive image of their agency. Furthermore, it also likely helps them discuss their work with different actors - colleagues, supervisors, politicians or the media. In client work, this strategy may help public servants address clients' situations adeptly, tolerantly and openly, permitting various options (see also Stout, 2013). Such multifaceted agency can be pivotal in a welfare state that values the development of human capabilities (Miettinen, 2013), particularly when interacting with children, elderly people, and other groups whose agency in society is underdeveloped or weakened (Fotaki, 2011).

For practitioners, the study highlights the importance of analyzing the compatibilities between discourses when introducing new approaches and discourses in an organization. Service reforms typically introduce and champion a single approach, such as NPM (Olakiviand Niska, 2017; Rosenthal and Peccei, 2006; Teelken, 2015), but those implementing the reforms might need to combine several approaches to support client relationships holistically. As argued above, diverse perspectives may increase public servants' capacity to solve contradictory client situations. However, organizations and professional education institutions could support public servants by allowing such diversity and by acknowledging and supporting the multifaceted nature of agency at work (see also Kruyen et al., 2019; Stout, 2009).

The study highlights several possibilities for further research. The discourse analytic method showed in a nuanced manner the tensions that public servants face and helps reveal the relational and multifaceted character of their agency. However, the small sample does not permit generalization to other individuals or organizations. As discussed above, similar tensions and discursive coping strategies may appear in other settings involving contradictory client relationships, but representations are likely context-specific. Thus, more research on the strategies for representing one's agency in different settings is needed. Furthermore, the study provides limited knowledge of the reality behind language, such as interviewees' beliefs, capabilities and non-linguistic practices, which condition their agency in client interactions. Future researchers are invited to explore longitudinally how public servants exercise their agency in public encounters and how their agency is transformed when client relationships and discourses change. Such research could combine studies of discursive and non-discursive layers of reality to provide a better understanding of interactions between discourses, organizational practices and the development of public servants' and clients' agency over time.

\section{References}

Alford, J. (2002), "Defining the client in the public sector: a social-exchange perspective", Public Administration Review, Vol. 62 No. 2, pp. 337-346.

Archer, M. (2003), Structure, Agency and the Internal Conversation, Cambridge University Press, Cambridge.

Aschhoff, N. and Vogel, R. (2018), "Value conflicts in co-production: governing public values in multiactor settings”, International Journal of Public Sector Management, Vol. 31 No. 7, pp. 775-793.

Bäcklund, P., Kallio, K.P. and Häkli, J. (2014), "Residents, customers or citizens? Tracing the idea of youthful participation in the context of administrative reforms in Finnish public administration", Planning Theory and Practice, Vol. 15 No. 3, pp. 311-327.

Bartels, K.P. (2013), "Public encounters: the history and future of face-to-face contact between public professionals and citizens", Public Administration, Vol. 91 No. 2, pp. 469-483. 
IJPSM 33,5

608

Bartels, K.P. (2018), "Collaborative dynamics in street level work: working in and with communities to improve relationships and reduce deprivation”, Environment and Planning C: Politics and Space, Vol. 36 No. 7, pp. 1319-1337.

Bartels, K.P. and Turnbull, N. (2019), "Relational public administration: a synthesis and heuristic classification of relational approaches", Public Management Review, Preprint, doi: 10.1080/ 14719037.2019.1632921.

Bévort, F. and Suddaby, R. (2016), "Scripting professional identities: how individuals make sense of contradictory institutional logics", Journal of Professions and Organization, Vol. 3 No. 1, pp. 17-38.

Boyte, H.C. (2011), "Constructive politics as public work: organizing the literature”, Political Theory, Vol. 39 No. 5, pp. 630-660.

Bryer, T.A. (2007), "Toward a relevant agenda for a responsive public administration”, Journal of Public Administration Research and Theory, Vol. 17 No. 3, pp. 479-500.

Bryer, T.A. (2009), "Explaining responsiveness in collaboration: administrator and citizen role perceptions", Public Administration Review, Vol. 69 No. 2, pp. 271-283.

Bryson, J.M., Crosby, B.C. and Bloomberg, L. (2014), "Public value governance: moving beyond traditional public administration and the new public management", Public Administration Review, Vol. 17 No. 4, pp. 445-456.

Burkitt, I. (2016), "Relational agency: relational sociology, agency and interaction", European Journal of Social Theory, Vol. 19 No. 6, pp. 322-339.

Castells, M. and Himanen, P. (2002), The Information Society and the Welfare State: The Finnish Model, Oxford University Press, Oxford.

Denhardt, J.V. and Denhardt, R.B. (2015), "The new public service revisited”, Public Administration Review, Vol. 17 No. 5, pp. 664-672.

Dobson, R. (2015), "Power, agency, relationality and welfare practice", Journal of Social Policy, Vol. 44 No. 4 , pp. $687-705$.

Donati, P. and Archer, M. (2015), The Relational Subject, Cambridge University Press, Cambridge.

Emerson, K., Nabatchi, T. and Balogh, S. (2011), "An integrative framework for collaborative governance", Journal of Public Administration Research and Theory, Vol. 22 No. 1, pp. 1-29.

Emirbayer, M. and Mische, A. (1998), "What is agency?”, American Journal of Sociology, Vol. 103 No. 4, pp. 962-1023.

Evans, T. (2010), "Professionals, managers and discretion: critiquing street-level bureaucracy", The British Journal of Social Work, Vol. 41 No. 2, pp. 368-386.

Fairclough, N. (2003), AnalysingDiscourse: Textual Analysis for Social Research, Routledge, London.

Fairclough, N. (2005), "Peripheral vision: discourse analysis in organization studies: the case for critical realism", Organization Studies, Vol. 26 No. 6, pp. 915-939.

FitzPatrick, M., Varey, R.J., Grönroos, C. and Davey, J. (2015), "Relationality in the service logic of value creation”, Journal of Services Marketing, Vol. 29 Nos 6/7, pp. 463-471.

Fotaki, M. (2011), "Toward developing new partnerships in public services: users as consumers, citizens and/or co-producers in health and social care in England and Sweden", Public Administration, Vol. 89 No. 3, pp. 933-955.

Giddens, A. (1984), The Constitution of Society: Outline of the Theory of Structuration, University of California Press, Berkeley.

Häikiö, L. (2012), "From innovation to convention: legitimate citizen participation in local governance", Local Government Studies, Vol. 38 No. 4, pp. 415-435.

Hirvonen, H. (2014), "From embodied to disembodied professionalism? Discussing the implications of medico-managerial management in welfare service work", Social Policy and Administration, Vol. 48 No. 5, pp. 576-593. 
Juvonen, T. (2013), "Nuorten aikuisten autonomisen toimijuuden jännitteinen rakentuminen ammatillisen etsivän nuorisotyön kontekstissa”, in Laitinen, M. and Niskala, A. (Eds.), Asiakkaat toimijoina sosiaalityössä, Osuuskunta Vastapaino, Tampere, pp. 327-356.

Juvonen, T. (2014), "Fragile agencies in the making", Young, Vol. 22 No. 3, pp. 253-269.

Kallio, K.P., Häkli, J. and Bäcklund, P. (2015), "Lived citizenship as the locus of political agency in participatory policy", Citizenship Studies, Vol. 19 No. 1, pp. 101-119.

Koivisto, P.. (2010), "Preparing for working life: effects of group counselling on adolescents' career development and mental health", Ph.D.dissertation, in People and Work Research Reports 92, Finnish Institute of Occupational Health, Tampereenyliopistopaino Oy - Juvenes Print, Tampere.

Koivisto, P., Vinokur, A.D. and Vuori, J. (2011), "Effects of career choice intervention on components of career preparation”, The Career Development Quarterly, Vol. 59 No. 4, pp. 345-366.

Koppell, J.G. (2005), "Pathologies of accountability: ICANN and the challenge of "multiple accountabilities disorder", Public Administration Review, Vol. 65 No. 1, pp. 94-108.

Kruyen, P., Keulemans, S., Borst, R.T. and Helderman, J.-K. (2019), "Searching for the renaissance bureaucrat: a longitudinal computer-assisted study of personality traits in government vacancies", International Journal of Public Sector Management, Vol. 33 No. 1, pp. 22-44.

Lazarides, R., Viljaranta, J., Ranta, M. and Salmela-Aro, K. (2017), “Adolescents' preparedness and motivation across the transition to post-comprehensive education", Contemporary Educational Psychology, Vol. 49, pp. 151-159.

Lipsky, M. (1980), Street-Level Bureaucracy: Dilemmas of the Individual in Public Services, Russel Sage Foundation, New York, NY.

Miettinen, R. (2013), Innovation, Human Capabilities and Democracy: Toward an Enabling Welfare State, Oxford University Press, Oxford.

Miles, M.B. and Huberman, A.M. (1994), Qualitative Data Analysis: An Expanded Sourcebook, 2nd ed., Sage Publications, Thousand Oaks, CA.

Nordlund, A., Sekki, S., Korvela, P. and Silvonen, J. (2019), "The changing everyday life of families and young people", in Toivonen, M. and Saari, E. (Eds.), Human-Centered Digitalization and Services, Springer, Singapore, pp. 79-100.

Nurmi, J.-E., Salmela-Aro, K. and Koivisto, P. (2002), "Goal importance and related achievement beliefs and emotions during the transition from school to work: antecedents and consequences", Journal of Vocational Behaviour, Vol. 60, pp. 241-261.

Olakivi, A. and Niska, M. (2017), "Rethinking managerialism in professional work: from competing logics to overlapping discourses", Journal of Professions and Organization, Vol. 4 No. 1, pp. 20-35.

Osborne, S.P., Radnor, Z. and Strokosch, K. (2016), "Co-production and the co-creation of value in public services: a suitable case for treatment?", Public Management Review, Vol. 18 No. 5, pp. 639-653.

Pache, A.-C. and Santos, F. (2013), "Embedded in hybrid contexts: how individuals in organizations respond to competing institutional logics", Institutional Logics in Action, Vol. 39 Part B, pp. 3-35.

Potter, J.. (2012), "Re-reading discourse and social psychology: transforming social psychology", British Journal of Social Psychology, Vol. 52 No. 3, pp. 436-455.

Potter, J. and Wetherell, M. (1987), Discourse and Social Psychology: Beyond Attitudes and Behavior, Sage Publications, London.

Raffo, C. and Reeves, M. (2000), "Youth transitions and social exclusion: developments in social capital theory", Journal of Youth Studies, Vol. 3 No. 2, pp. 147-166.

Rosenthal, P. and Peccei, R. (2006), "The social construction of clients by service agents in reformed welfare administration", Human Relations, Vol. 59 No. 12, pp. 1633-1658.

Rosenthal, P. and Peccei, R. (2007), "'The work you want, the help you need': constructing the customer in Jobcentre plus", Organization, Vol. 14 No. 2, pp. 201-223. 
IJPSM 33,5

Rostila, I. and Vinnurva, J. (2013), "Sosiaalityön asiakkaan toimijuus ja täysimittainen professionaalisuus", in Laitinen, M. and Niskala, A. (Eds.), Asiakkaat toimijoina sosiaalityössä, Osuuskunta Vastapaino, Tampere, pp. 196-218.

Schott, C., van Kleef, D. and Noordegraaf, M. (2016), "Confused professionals? Capacities to cope with pressures on professional work", Public Management Review, Vol. 18 No. 4, pp. 583-610.

Siurala, L. (2014), "Autonomy through dependency: histories of co-operation, conflict and innovation in youth work", in Siurala, L., Coussée, F., Suurpää, L. and Williamson, H. (Eds.), The History of Youth Work in Europe: Autonomy through Dependency, Council of Europe Publishing, Strasbourg, pp. 161-177.

Siurala, L., Coussée, F., Suurpää, L. and Williamson, H. (Eds.) (2014), The History of Youth Work in Europe: Autonomy through Dependency, Council of Europe Publishing, Strasbourg.

Skelcher, C. and Smith, S.R. (2015), "Theorizing hybridity: institutional logics, complex organizations, and actor identities: the case of nonprofits", Public Administration, Vol. 93 No. 2, pp. 433-448.

Statistics Finland (2009), Entrance to Education, Statistics Finland, Helsinki, available at: http://www. stat.fi/til/khak/index_en.html.

Stout, M. (2009), "Enhancing professional socialization through the metaphor of tradition”, Journal of Public Affairs Education, Vol. 15 No. 3, pp. 289-316.

Stout, M. (2013), Logics of Legitimacy: Three Traditions of Public Administration Praxis, Taylor \& Francis, New York, NY.

Stout, M. and Love, J.M. (2015), "Relational process ontology: agrounding for global governance", Administration \& Society, Vol. 47 No. 4, pp. 447-481.

Stout, M. and Love, J.M. (2017), "Integrative governance: amethod for fruitful public encounters", The American Review of Public Administration, Vol. 47 No. 1, pp. 130-147.

Teelken, C. (2015), "Hybridity, coping mechanisms, and academic performance management: comparing three countries", Public Administration, Vol. 93 No. 2, pp. 307-323.

Tummers, L.L., Bekkers, V., Vink, E. and Musheno, M. (2015), "Coping during public service delivery: a conceptualization and systematic review of the literature", Journal of Public Administration Research and Theory, Vol. 25 No. 4, pp. 1099-1126.

Vigoda, E. (2002), "From responsiveness to collaboration: governance, citizens, and the next generation of public administration”, Public Administration Review, Vol. 62 No. 5, pp. 527-540.

\section{Further reading}

Edwards, A.. (2005), "Relational agency: learning to be a resourceful practitioner", International Journal of Educational Research, Vol. 43 No. 3, pp. 168-182.

\section{Appendix 1}

Interview guide.

The main interview themes and sub-themes relevant for this paper are summarized below.

\section{Background}

- What is your position and job?

- What is going on in your work currently?

- Have you experienced recent changes in services or the organization?

(1) Service development and client orientation

- Who do you treat as the clients of these services? 
- How do you interact with clients?

- To what extent/how do client needs guide your organization?

- How do you process client needs/demands?

- How do you solve challenging client situations?

(2) Example of a service-related change initiative

(3) Leadership and employee roles in service development

(4) Well-being at work

- How do you define well-being at work?

- What increases your resources/exhausts you at work?

\section{Corresponding author}

Tiina Tuominen can be contacted at: tiina.tuominen@tuni.fi
Public servants

coping with competing demands

\section{1}

For instructions on how to order reprints of this article, please visit our website: www.emeraldgrouppublishing.com/licensing/reprints.htm Or contact us for further details: permissions@emeraldinsight.com 